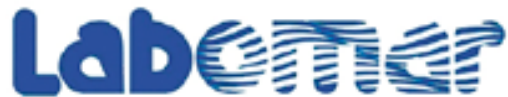

Arquivos de Ciências do Mar

\section{EFFECT OF DREDGING ON HG DISTRIBUTION IN WATER AND SEDIMENTS IN THE MUCURIPE HARBOR, FORTALEZA, NE, BRAZIL}

\section{Efeito da dragagem na distribuição de $\mathrm{Hg}$ em água e sedimentos no Porto Mucuripe, Fortaleza, NE, Brasil}

\section{Luiz Drude de Lacerda ${ }^{1}$, Ingra Kellen Cavalcante Belmino², Lucas Moreira Buruaem³, Rozane Valente Marins ${ }^{4}$}

\author{
${ }^{1}$ Professor do Labomar/UFC e pesquisador do CNPq \\ ${ }^{2}$ Cientista ambiental e mestra em Ecologia pela UFC \\ ${ }^{3}$ Biólogo e pesquisador do Núcleo de Estudos em Poluição e Ecotoxicologia Aquática (Nepea), Unesp, São Vicente, SP \\ ${ }^{4}$ Professora do Labomar/UFC, coordenadora do Laboratório de Biogeoquímica Costeira e pesquisadora do CNPq \\ E-mail par correspondência: Idrude1956@gmail.com
}

\begin{abstract}
Dredging and tailings disposal can mobilize mercury $(\mathrm{Hg})$ accumulated in bottom sediments, increasing the exposure of the aquatic biota. In the Mucuripe Harbor, NE, Brazil, dredging is performed regularly, but the impact on $\mathrm{Hg}$ mobilization is unknown. This paper presents results from the monitoring of a dredging operation to characterize and quantify an eventual $\mathrm{Hg}$ mobilization. The results showed that remobilization is significant and is associated with suspended solids. Further deposition of the Hg-enriched, remobilized, suspended solids increased Hg concentrations by a factor of 1.2 and 2.0 in harbor and shelf sediments, respectively. Maximum concentrations in harbor and shelf sediments reached $79.9 \mathrm{ng} \cdot \mathrm{g}^{-1}$ and $32.4 \mathrm{ng} \cdot \mathrm{g}^{-1}$ (20 and 9 higher than the regional background, respectively). The progressive increase in $\mathrm{Hg}$ concentrations may result in higher exposure to the local biota.
\end{abstract}

Keywords: metals, mobilization, contamination, coastal sediments.

\section{RESUMO}

Dragagem e destinação de rejeitos no porto do Mucuripe, em Fortaleza, NE, Brasil, aumentaram a mobilização de $\mathrm{Hg}$ associada aos sólidos suspensos e às concentrações de $\mathrm{Hg}$ por um fator de 1,2 e 2,0 em sedimentos de porto e plataforma continental, respectivamente.

Recebido em: 18/9/2019

Aprovado em: 22/10/2019

Publicado online em: 20/3/2020 
As concentrações máximas em sedimentos do porto, de 79,9 ng.g-1, embora baixas quando comparadas a outras áreas contaminadas em portos brasileiros, representam um aumento de 20 vezes relativo ao valor de fundo regional. Os sedimentos adjacentes da plataforma continental, com concentrações máximas de 32,4 ng.g-1, também influenciados por rejeitos, são 9 vezes maiores. $\mathrm{O}$ aumento progressivo das concentrações de $\mathrm{Hg}$ pode estar associado ao teor de $\mathrm{Hg}$ anormalmente elevado observado em peixes locais.

Palavras-chave: metais, mobilização, contaminação, sedimentos costeiros.

\section{INTRODUCTION}

Dredging to keep navigable harbor accesses and maneuvering areas changes the chemical and biological characteristics of bottom sediments and the overlying water column, both at the operation and at disposals sites (Caplat et al., 2005), generally increasing sediment toxicity (Baruaem et al., 2012; Moreira et al., 2017; Saes et al., 2019). Amongst these changes, the mobilization of contaminants is of relevant environmental concern, in particular those elements quickly incorporated into food chains that may result in increasing exposure to pollutants. The importance of such an environmental issue led to the promulgation of a specific regulatory legislation in many countries. In Brazil, the Conama Resolution 344/2012 (Conama, 2012) establishes legal limits for pollutant concentrations in sediments subjected to dredges and their disposal. However, results from different harbor areas worldwide, strongly suggest that even with concentrations lower than legal limits increasing exposure to pollutants may cause deleterious effects to the biota (Van den Hurk et al., 1997).

Among the contaminants which can suffer chemical changes due to dredging, $\mathrm{Hg}$ has been reported to suffer intense remobilization, having its chemical speciation in water changed, its distribution in bottom sediments modified and its bioavailability to the biota increased, due to the mobilization of readily bioaccumulated species, in particular methyl mercury (MeHg). Mercury is regulated under the Conama (2012) act and the proposed limit concentrations in sediments range from the Level 1 (300 ng.g-1), when no specific disposal is required, to Level $2\left(1,000 \mathrm{ng}^{\left.-\mathrm{g}^{-1}\right)}\right.$, when pre-disposal treatment is required. These concentrations, however, may be 10 to 100 times higher than the local background of $\mathrm{Hg}$ in Brazilian shelf sediments (Marins et al., 2004). A critical review of $\mathrm{Hg}$ sediment quality values (SQV) for the protection of benthic invertebrates shows low predictive value of SQVs when Hg concentrations are above background levels (Conder et al., 2015), in Brazilian shelf sediments background $\mathrm{Hg}$ concentrations are on the order of 5 to $30 \mathrm{ng}^{-g^{-1}}$ (Marins et al., 2004). Therefore, virtually any dredging of merely Hg-enriched sediments can pose environmental threats to aquatic organism.

The top few centimeters of the sediment is the most dynamic layer, both for $\mathrm{Hg}$ methylation and diagenesis, therefore, even small dredging operations can increase $\mathrm{Hg}$ bioavalability (Bloom \& Lasorca, 1999). In addition, during dredging and disposal of tailings, $\mathrm{Hg}$ present in sediments reacts with other compounds such as organic carbon and sulfate in an oxic environment maximizing its remobilization (Shultz et al., 1995; Aquavita et al., 2012). Once mobilized, $\mathrm{Hg}$ can enter food chains increasing the environmental exposure to the biota and humans, through the ingestion of contaminated fish, in particular. 
In the Mucuripe Harbor, the oldest and largest maritime terminal in Fortaleza, NE Brazil, navigation canals and maneuvering areas require maintenance dreading on a 3 to 5 year basis. In the last dredging in 2011, the navigation canal was deepened to $14 \mathrm{~m}$ and the activity removed about 5.7 million cubic meters of sediments that were discharged offshore. During this period a monitoring program was established to follow eventual changes in the hydrochemistry, the distribution and composition of the local biota and the presence of contaminants (CDC, 2010). Since in the Mucuripe coastal region, previous studies on $\mathrm{Hg}$ distribution in the local environment had reported abnormal $\mathrm{Hg}$ concentrations in sediments (Marins et al., 2004; Baruarem et al., 2012) and in fishes commercialized in the local market (Costa \& Lacerda, 2009), the dredging and tailings disposal may contribute to a further increase in $\mathrm{Hg}$ bioavailability. Unfortunately, the impact on these activities on the $\mathrm{Hg}$ mobilization in the Mucuripe Harbor area is still unknown. Therefore, the accompanying of $\mathrm{Hg}$ concentrations in water, suspended particles and bottom sediments, in harbor and the adjacent shelf area during the 2011 dredging were performed, in order to verify if any $\mathrm{Hg}$ mobilization occurs and the mechanism responsible for any eventual increasing in $\mathrm{Hg}$ concentrations.

\section{MATERIAL AND METHODS}

In the harbor and in adjacent areas, sampling stations were established as depicted in Figure 1 for water and sediment collection. For the Hg quantification in water (9 stations), duplicate samples we collected only during the dredging operations, since any changes in $\mathrm{Hg}$ concentrations in water remain for only a short period previous to dilution and/or incorporation onto the solid phase (Salomons \& Forstner, 1984). Sediment samples (10 stations) were collected before (2007) and after the dredging, in 2011. Four (4) additional sampling stations for the collection of shelf sediment were established in areas outside the harbor, but sampling only occurred once in 2011. These additional stations were selected to coincide with previously sampled stations in 2002 (Maia, 2004) and were used for comparative purposes of temporal trends in $\mathrm{Hg}$ concentrations in local sediments.

Duplicate water samples were collected in Teflon $500 \mathrm{ml}$ bottles and immediately filtered in the laboratory $(0.45 \mu) \quad$ to determine dissolved $\mathrm{Hg}$ ( $\mathrm{Hg}$ D). Filtered water samples $(40 \mathrm{ml})$ were digested with

Figure 1 - Stations grid of sediment and water samples in the Mucuripe Harbor and adjacent shelf sediments, off Fortaleza, Northeastern Brazil

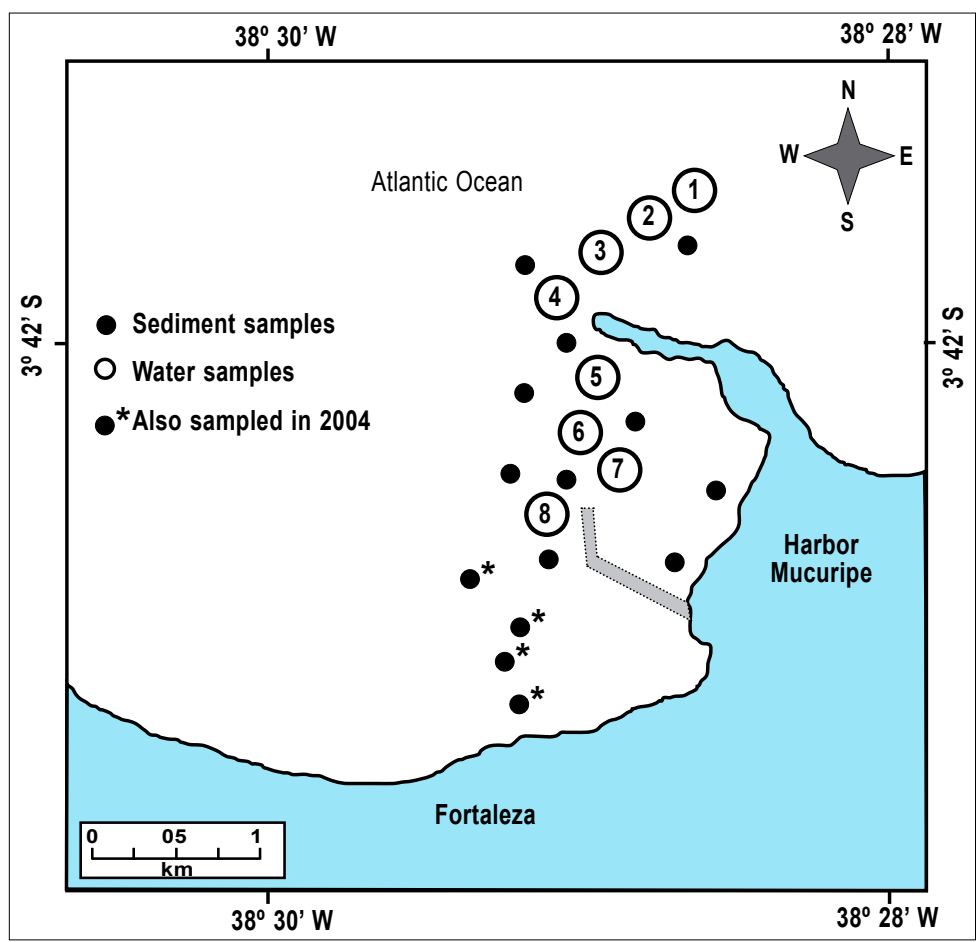


$7.5 \mathrm{ml}$ de $\mathrm{HCl}(4 \mathrm{~N})$, and $1.0 \mathrm{ml}$ of a $\mathrm{KBrO}_{3} / \mathrm{KBr}(0.1 \mathrm{~N})$ solution in Boeco glass vials for 30 min; after, $25 \mu \mathrm{L}$ of hydroxylamine $(12 \%)$, were added to reduce the excess potassium bromine. Particulate $\mathrm{Hg}(\mathrm{Hg}-\mathrm{P})$ were measured after the digestion of filters with $20 \mathrm{ml}$ of a $50 \%$ aqua regia solution $\left(\mathrm{H}_{2} \mathrm{O}: \mathrm{HCl}: \mathrm{HNO}_{3} ; 4: 3: 1\right)$ in $125 \mathrm{ml}$ Erlenmeyer flasks at $70{ }^{\circ} \mathrm{C}$ for one hour (Marins et al., 2002a). Hg-D and Hg-P were quantified in a PSA Millennium Merlin 10.025 cold vapor atomic fluorescence spectrometer (CVAFS), after reduction with $\mathrm{SnCl}_{2}$. The analytical precision, estimated as the relative percent difference between aliquots, was always less than $20 \%$. The recovery of known additions of $\mathrm{Hg}^{2+}$ to filtered marine waters averaged $92 \pm 4 \%$.

Duplicate sediment samples were collected using a Van Veen dredge, packed in plastic bags and kept refrigerated till analysis. Subsamples were dried at $50{ }^{\circ} \mathrm{C}$ till constant weight and sieved through $0.063 \mathrm{~mm}$ mesh. Dried duplicate samples weighting $1.0 \mathrm{~g}$ were leached with $20 \mathrm{ml}$ of $0.1 \mathrm{~N} \mathrm{HCl}$ after 2 hours contact in a shaker to extract the exchangeable fraction (Hg-Exch). Sequentially samples were digested in with $20 \mathrm{ml}$ of a $50 \%$ aqua regia solution $\left(\mathrm{H}_{2} \mathrm{O}: \mathrm{HCl}: \mathrm{HNO}_{3}\right.$; 4:3:1) in $125 \mathrm{ml}$ Erlenmeyer flasks at $70{ }^{\circ} \mathrm{C}$ for two hour to extract the strongly bound $\mathrm{Hg}$ fraction (Hg-Sb) present in sediments (Aguiar et al., 2007). Hg-Exch and $\mathrm{Hg}-\mathrm{Sb}$ were quantified in a Nippon Instruments Corporation (NIC) model RA3210A cold vapor atomic absorption spectrometer (CVAAS), after reduction with $\mathrm{SnCl}_{2}$. For quality assurance of the $\mathrm{Hg}$ determination in the TSS and sediments, a certified reference material (NRC PACS-2, Canada) was simultaneously analyzed ( $\mathrm{n}=6)$, and the analysis demonstrated an average $\mathrm{Hg}$ recovery of $103 \pm 4 \%$.

The $\mathrm{Hg}$ detection limits, estimated as three times the standard deviation of reagent blanks, was $0.30 \mathrm{ng} . \mathrm{g}^{-1}$ in suspended matter and sediment samples and $0.18 \mathrm{ng}^{-1} \mathrm{l}^{-1}$ in water samples. In all cases, the blank signals were lower than $0.5 \%$ of sample analysis. The concentration values were not corrected for the relative recoveries obtained for the certified material.

\section{RESULTS AND DISCUSSION}

Average Hg-D concentrations were below the detection limit of the method in all

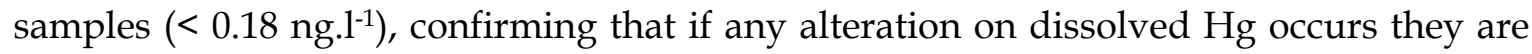
short-lived or involve very low concentrations. Dissolved $\mathrm{Hg}$ concentrations in coastal waters are generally lower than the detections limit of this study. Marins et al. (2002b) reported dissolved $\mathrm{Hg}$ concentrations in the contaminated Ceará River lower estuary between 1.2 and 1.7 ng..$^{-1}$ and of 0.06 to 1.07 ng.l-1 ${ }^{-1}$ in the Pristine Pacoti river lower estuary. Shelf waters present even lower concentrations varying from $<0.05$ to $0.48 \mathrm{ng}^{-1} \mathrm{l}^{-1}$ (Lacerda $\&$ Marcovecchio, 2018). Thus the relatively high detection limit and the single sampling strategy hamper a discussion of a possible impact of the dredging operations on the dissolved $\mathrm{Hg}$ concentrations.

Mean and range of concentrations of $\mathrm{Hg}-\mathrm{P}$ in water samples collected inside and outside the harbor area showed no significant difference, similar to the suspended particulate matter content (TSS). However, the Hg concentration in the TSS was significantly $(\mathrm{P}<0.05)$ higher inside the harbor area than in the outside samples (Table I), strongly suggesting a change of quality of the TSS through the contribution of Hg-enriched dredged materials to the suspended matter inside the harbor area. Typical concentrations in the TSS of coastal areas of Ceará state vary depending on $\mathrm{Hg}$ inputs, but in areas receiving effluents 
from the Fortaleza metropolitan region, $\mathrm{Hg}$ concentrations range from 13 to $166 \mathrm{ng} \cdot \mathrm{g}^{-1}$ (Marins et al., 2002b).

Enrichment of the TSS with $\mathrm{Hg}$ has been reported elsewhere and results either from remobilizing deeper, $\mathrm{Hg}$-enriched sediment layers, and release of dissolved $\mathrm{Hg}$ from interstitial waters that readily adsorbs onto the TSS (Bloom \& Lasorca, 1999). For example, highest $\mathrm{Hg}$ concentrations observed in Sepetiba Bay suspended matter, were suggested a result from frequent dredging for harbor maintenance and reflect ressuspension of bottom sediments, and typically present $\mathrm{Hg}$ contents ranging from 80

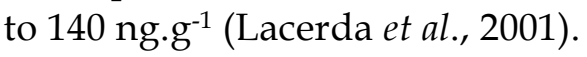

\begin{tabular}{|c|c|c|c|c|}
\hline Area & TSS (mg. l'1 $\left.^{-1}\right)$ & Hg-D (ng. 1 $\left.^{-1}\right)$ & Hg-P (ng. $\left.1^{-1}\right)$ & Hg-TSS (ng.g-1) \\
\hline Outside & $\begin{array}{c}21.2 \pm 1.8 \\
19.0-22.6\end{array}$ & $<0.18 \mathrm{ng} .1^{-1}$ & $\begin{array}{l}2.10 \pm 0.38 \\
1.75-2.54\end{array}$ & $\begin{array}{c}99.0 \pm 16.5 \\
77.4-112.3\end{array}$ \\
\hline Inside & $\begin{array}{c}19.2 \pm 3.2 \\
15.6-22.2\end{array}$ & $<0.18{\text { ng. } .1^{-1}}^{-1}$ & $\begin{array}{l}2.45 \pm 0.17 \\
2.32-2.41\end{array}$ & $\begin{array}{c}129.7 \pm 17.3 \\
111.5-151.5\end{array}$ \\
\hline
\end{tabular}

Sediment $\mathrm{Hg}$ concentrations, TOC and fine sediment contents measured before and after the dredging operation are shown in Table II. Data from 2007, prior to the dredging activities, showed harbor sediments enriched in $\mathrm{Hg}$, TOC and fine sediments, relative to shelf sediments outside the harbor area. After the dredging, which deepened harbor depth from 5-6 to 10-13 m, both harbor and shelf sediments were enriched in $\mathrm{Hg}$ and fine sediments. Regarding the TOC content only shelf sediments were enriched after the dredging. Hg concentrations increased by 1.2 and 2.0 times in harbor and shelf sediments, respectively, from 2007 to 2011. However, the increase in $\mathrm{Hg}$ concentrations was more significant in shelf sediments. In 2007 harbor/shelf $\mathrm{Hg}$ concentrations ratio was 3.0 (34.6 to

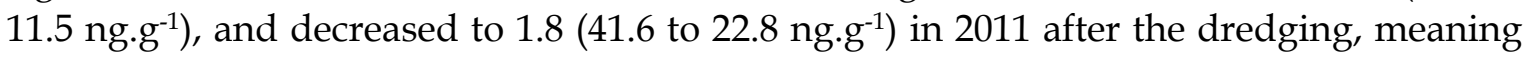
that concentrations in shelf sediments were nearly doubled due to tailings disposal. Fine sediment contents increased 6.1 and 8.3 times in harbor and shelf sediments, respectively, from 2007 to 2011. The higher concentrations of $\mathrm{Hg}$ and fine sediments in the harbor are after the dredging, suggest that exposure of deeper layers occurred, and is consistent with high $\mathrm{Hg}$ concentrations observed in the TSS.

Maximum (79.9 ng.g ${ }^{-1}$ d.w.) and average (41.6 ng.g ${ }^{-1}$ d.w.) Hg concentrations in harbor sediments are low compared to other harbor areas in Brazil. In sediments of the largest Santos Harbor in SE Brazil, Baruarem et al. (2012) reported a maximum (640 ng.g-1 d.w.) and average (260 ng.g-1 d.w.) Hg concentrations; respectively 8.0 and 6.5 times higher than the concentrations observed in the Mucuripe Harbor. Compared to industrial harbors, such as Baltimore and Boston Harbors, the observed concentrations in the Mucuripe Harbor sediments are 10 to 100 times lower (Mason and Lawrence, 1999). 
Table II - Mercury, total organic carbon (TOC) and fine sediment $(<63 \mu)$ contents is sediments inside the Mucuripe Harbor and in adjacent shelf areas affected by the release of dredge tailings, before (2007) and after (2011) dredging operations. TOC and fine sediment data from Baruaem et al. (2012)

\begin{tabular}{cccccc}
\hline \multicolumn{2}{c}{ Hg (ng.g ${ }^{-1}$ d.w.) } & \multicolumn{2}{c}{ TOC (\%) } & \multicolumn{2}{c}{$\boldsymbol{\theta}<63 \boldsymbol{\mu}$} \\
\hline Shelf & Harbor & Shelf & Harbor & Shelf & Harbor \\
\hline & \multicolumn{2}{c}{2007} \\
$11.5 \pm 13.1$ & $34.6 \pm 8.2$ & $0.4 \pm 0.4$ & $1.1 \pm 0.3$ & $6.5 \pm 8.7$ & $12.5 \pm 10.1$ \\
$0.02-32.6$ & $25.8-46.2$ & $0.1-1.1$ & $0.8-1.4$ & $0.1-16.7$ & $2.4-22.7$
\end{tabular}

\begin{tabular}{cccccc}
\multicolumn{5}{c}{2011} \\
$22.8 \pm 15.7$ & $41.6 \pm 23.9$ & $2.7 \pm 5.2$ & $1.0 \pm 0.6$ & $54.0 \pm$ & $76.3 \pm 14.2$ \\
$4.4-38.2$ & $24.4-79.9$ & $0.1-10.5$ & $0.4-1.9$ & $1.8-95.3$ & $56.0-90.1$ \\
\hline
\end{tabular}

Mean $\mathrm{Hg}$ concentrations in shelf sediment reported in 2002 were $3.4 \pm 3.0 \mathrm{ng} \mathrm{g}^{-1}$ (Maia, 2004). In 2011, the same stations doubled their average $\mathrm{Hg}$ concentrations to $7.3 \pm 1.9$ ng.g ${ }^{-1}$. This confirms a significant increase during this 7-year period. After that sampling, in 2002, the harbor suffered its first two large dredging operations of about 1.0 and 3.0 million cubic meters, in 2003 and 2004, respectively. From its construction in 1991 and 2003, two small operations (< 0.8 million cubic meters) occurred. Therefore, the increased concentrations verified in shelf sediments, may be associated with the dredging operations between 2002 and 2011. All operations discharged tailings in nearby shelf areas.

Moreover, considering the regional background estimated by Marins et al. (2004), the average and maximum $\mathrm{Hg}$ concentrations in the Mucuripe Harbor sediments (41.6 and 79.9 ng. ${ }^{-1}$, respectively), represents a 8 and 20 times increase relative to regional background, whereas the average and maximum concentrations in adjacent shelf sediments influenced by

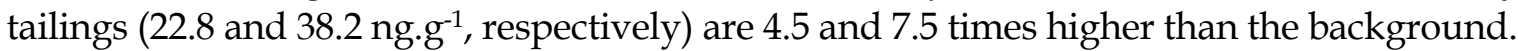

Modeling of the expected increase in $\mathrm{Hg}$ uptake by fish, in areas suffering $\mathrm{Hg}$ mobilization due to dredging and sediments disposal estimated a 30\% increase of $\mathrm{Hg}$ concentrations in carnivorous fish (Schultz et al., 1995). At the Kaohsiung Harbor, Taiwan, $\mathrm{MeHg}$ level showed a positive correlation with the total $\mathrm{Hg}$ and total organic carbon in the sediments, reaching from $<0.01$ to $2.66 \%$ of the total $\mathrm{Hg}$ content in the sediments, suggesting that increasing $\mathrm{Hg}$ and TOC contents in sediments, as observed for the shelf sediments at the Mucuripe area, also increase Hg bioavailability (Chen et al., 2018). Similarly, in Baltimore Harbor sediments, Mason and Lawrence (1999) highlighted the importance of organic matter in regions removed from point source input in controlling both the concentration and bioavailability of $\mathrm{MeHg}$ to organisms. Based on these and other evidence from dredging of harbor sediments worldwide, as reviewed by Conder et al. (2015), the progressive increase in $\mathrm{Hg}$ concentrations, together with TOC in sediments of shelf areas surrounding the Mucuripe Harbor may increase the already observed anomalously high Hg content observed in local fish (Costa \& Lacerda, 2009; Lacerda et al., 2016).

\section{CONCLUSIONS}

Mercury mobilization due to dredging in different parts of the world suggests a significant increase of $\mathrm{Hg}$ bioavailability by favoring $\mathrm{MeHg}$ production and thus increasing 
Hg concentrations in carnivorous fish. These observations prevented or altered sediment dredging and dredging techniques in many regions. Unfortunately, for the Mucuripe Harbor, the scarce data on $\mathrm{Hg}$ distribution in the local food chains, as well as of regular monitoring of environmental parameters of the harbor area, impede a cause-effect relationship to be quantified. However, the increasing trend verified in local coastal sediments, between 2003 and 2011, and the Hg enrichment in suspended solids and surface bottom sediments of adjacent areas observed in this study, associated with an enrichment of TOC in these same sediments, may support an association with the $\mathrm{Hg}$ concentrations in local fish and of the estimated exposure to $\mathrm{Hg}$ by consumers. Therefore, our results strongly suggest the characterization of the $\mathrm{Hg}$ behavior and fate should be included in EIA studies of future dredging operation in the Mucuripe Harbor.

\section{BIBLIOGRAPHIC REFERENCES}

Acquavita, A.; Emili, A.; Covelli, S.; Faganeli, J.; Predonzani, S.; Koron, N. \& Carrasco, L. The effects of resuspension on the fate of $\mathrm{Hg}$ in contaminated sediments (Marano and Grado Lagoon, Italy): Short-term simulation experiments. Estuar. Coast. Shelf Sci., London, v. 113, n. 1, p. 32-40, 2012.

Aguiar, J.E.; Marins, R.V. \& Almeida, M.D. Comparação de metodologias de digestão de sedimentos marinhos para caracterização da geoquímica de mercúrio. Geochim. Bras., Rio de Janeiro, v. 3, n. 21, p. 304-323, 2007.

Baruaem, L.M.; Hortellani, M.A.; Sarkis, J.E.; Costa-Lotufo, L.V. \& Abessa, D.M.S. Contamination of port zone sediments by metals from Large Marine Ecosystems of Brazil. Mar. Pollut. Bull., London, v. 64, p. 479-488, 2012.

Bloom, N. \& Lasorca, B.K. Changes in mercury speciation and the release of 3 methyl mercury as a result of marine sediment dredging activities. Sci. Tot. Environ., London, v. 237-238, p. 379-385, 1999.

Chen, C-F.; Ju, Y-R.; Lin, G-T.; Chen, C-W. \& Dong, C-D. Methylmercury in industrial harbor sediments in Taiwan: first observations on its occurrence, distribution, and measurement. Int. J. Environ. Res. Public Health., v. 15, n. 1765, p. 1-13, 2018.

Conama. Conselho Nacional do Meio Ambiente. Resolução $n^{\circ} 454 / 12$. Estabelece as diretrizes gerais e os procedimentos referenciais para o gerenciamento do material a ser dragado em águas sob jurisdição nacional. Conama, 18 p., Brasília, 2012.

Conder, J.M.; Fuchsman, P.C.; Grover, M.M.; Margar, V.S. \& Henning, M.H. Critical review of mercury sediment quality values for the protection of benthic invertebrates. Environ. Toxicol. Chem., v. 34, n. 1, p. 6-21, 2015.

Caplat, C.; Texier, H.; Barillier, D. \& Lelievre, C. Heavy metals mobility in harbor contaminated sediments: the case of Port-en-Bessin. Mar. Pollut. Bull., London, v. 50, p. 504511, 2005.

CDC. Companhia Docas do Ceará. Projeto da segunda etapa da dragagem de aprofundamento do porto de Fortaleza. CDC, 67 p., Fortaleza, 2010.

Costa, B.G.B. \& Lacerda, L.D. Concentração de mercúrio total em cavala (Scomberomorus cavala Cuvier, 1829) e serra (Scomberomorus brasiliensis Collette, Russo \& Zavala-Camin, 
1978) comercializados nas bancas de pescado do Mucuripe, Fortaleza, CE. Arq. Ciên. Mar, Fortaleza, v. 42, n. 1, p. 22-29, 2009.

Lacerda L.D.; Marins, R.V.; Paraquetti, H.H.M.; Mounier, S.; Benaim, J. \& Frevier, D. Mercury distribution and reactivity in waters of a sub-tropical coastal lagoon, Sepetiba Bay, SE, Brazil. J. Braz. Chem. Soc., v. 12, n. 1, p. 93-98, 2001.

Lacerda, L.D.; Bezerra, M.F.; Costa, B.G.B.; Braga, T.M. \& Goyanna, F.A.A. Mercury distribution in fish commercialized in the Mucuripe market, Fortaleza, CE, Brazil. Arq. Ciên. Mar, Fortaleza, v. 49, n. 1, p. 50-54, 2016.

Lacerda, L.D. \& Marcovecchio, J.E. Continent derived metal pollution through time: challenges of the global ocean, p. 99-117, in Arias, A.H. \& Marcovecchio, J.E. (eds.), Marine Pollution and Climate Change. CRCPress, Boca Raton, 2018.

Maia, S.R.R. Distribuição e partição geoquímica de metais-traço na costa norte de Fortaleza, CE. Dissertação de mestrado, Programa de Pós- Graduação em Ciências Marinhas Tropicais, Universidade Federal do Ceará, 106 p., Fortaleza, 2004.

Marins, R.V.; Paraquetti, H.H.M. \& Ayres, G.A. Alternativa analítica para a determinação físico-química de mercúrio em águas costeiras tropicais. Quím. Nov., São Paulo, v. 25, n. 3, p. 372-378, 2002a.

Marins, R.V.; Lacerda, L.D.; Mounier, S.; Paraquetti, H.H.M. \& Marques, W.S. Caracterização hidroquímica, distribuição e especiação de mercúrio nos estuários dos rios Ceará e Pacoti, Região Metropolitana de Fortaleza, Ceará, Brasil. Geoch. Bras., v. 16, n. 1, p. 37-48, 2002b.

Marins, R.V.; Paula Filho, F.J.; Lacerda, L.D.; Rodrigues, S.R. \& Marques, W.S. Distribuição de mercúrio total como indicador de poluição urbana e industrial na costa brasileira. Quím. Nov., São Paulo, v. 27, n. 5, p. 763-770, 2004.

Mason, R.P. \& Lawrence, A.L. Concentration, distribution, and bioavailability of mercury and methylmercury in sediments of Baltimore Harbor and Chesapeake Bay, Maryland, USA. Environ. Toxicol. Chem., v. 18, n. 11, p. 2438-2447, 1999.

Moreira, L.B.; Castro, I.B.; Hortellani, M.A.; Sasaki, S.T.; Taniguchi, S.; Petti, M.A.V.; Fillmann, G.; Sarkis, J.E.S.; Bícego, M.C.; Costa-Lotufo, L.V. \& Abessa, D.M.S. Effects of harbor activities on sediment quality in a semi-arid region in Brazil. Ecotoxicol. Environ. Safe., London, v. 135, p. 137-151, 2017.

Saes, R.V.S.; Moreira, L.B.; Peres, T.F.; Taniguchi, S.; Bícego, M.C.; Marins, R.V. \& Abessa, D.M.S. Sub-lethal responses of the polychaete armandia agilis in whole sediment toxicity testing. Bull. Environ. Contamin. Toxicol., Berlin, v. 102, p. 310-315, 2019.

Salomons, W. \& Forstner, U. Metals in the hydrocycle. Springer, Berlin, 347 p., 1984.

Schultz, T.; Korhonen, P. \& Virtanen, M. A mercury model used for assessment of dredging impacts.Wat. Air Soil Pollut., Dordrecht, v. 80, p. 1171-1180, 1995.

Van den Hurk, P.; Eertman, R.H.M. \& Stronkhorst, J. Toxicity of harbour canal sediments before dredging and after off-shore disposal. Mar. Pollut. Bull., v. 34, p. 244-249, 1997. 